\title{
PREOVULATORY AND OVULATORY MECHANISMS IN OOCYTE MATURATION
}

\author{
G. THIBAULT, MIGHELINE GERARD AND Y. MENEZO \\ I.N.R.A., Physiologie Animale, 78350 Fouy-en-Fosas, France
}

\begin{abstract}
Summary. Studies of the effect of gonadotrophins on the cumulus and oocyte or on the whole follicle in vitro offer a good tool for understanding the mechanisms of oocyte maturation, the ability of follicles of different sizes to respond to gonadotrophins and the processes of atresia. The birth of normal young from intrafollicular oocytes matured in vitro furnishes proof that in-vitro techniques are valuable as long as follicular integrity is maintained during the whole culture period.
\end{abstract}

Three main events occur during the preovulatory period before the ovulation of a normal and fertilizable oocyte: (i) cytoplasmic and nuclear maturation of the oocyte; (ii) disruption of cumulus cell cohesiveness among the cells of the granulosa layer; (iii) thinning and opening of the external follicular wall. Extending these three areas of investigation one may ask: (iv) why do only a very limited number of Graafian follicles in vivo respond to gonadotrophins; and $(v)$ why do the other Graafian follicles become atretic?

Since 1967 we have developed in-vitro techniques as tools for the study of these aspects of ovarian physiology. The results thus obtained and others from the literature are mentioned and discussed in this paper.

\section{DISRUPTION OF THE COHESIVENESS OF THE GUMULUS GELLS}

In the growing follicles of some species, e.g. rabbit, the oocyte remains in a subcentral position suspended by pillars of cumulus cells which join the granulosa cells at many points. In primates, ruminants and many other mammals, cumulus cells of growing Graafian follicles are cytologically indistinguishable from the granulosa cells, although metabolic exchange with the egg occurs through this area, the discus proligerus, during follicular growth. After cyclic surges of gonadotrophins, cavities appear inside the cumulus mass and the cells become progressively separated from each other. Only the cumulus cells anchored in the zona pellucida remain surrounding the oocyte and forming the corona radiata (Pl. 1, Fig. 1). As soon as separation of the cumulus cells begins, metabolic exchange can occur only through the follicular fluid, and oocyte maturation in vivo is accomplished in a type of in-vitro culture system in this medium which is chemically similar to blood serum, although more diluted (Edwards, 1974; Menezo \& Testart, 1975).

Metabolic exchange is probably easier in small mammals with small pre- 
ovulatory follicles, since the volume of fluid in which the cumulus cells and oocytes are supported is less than that in ruminants or primates. It is not known if there is a relationship between the duration of final maturation and follicle size, but follicle and oocyte maturation does not exceed $12 \mathrm{hr}$ in species with small follicles, and 1-2 days in species with follicles of $>10 \mathrm{~mm}$ in diameter.

Culture of cumulus cells recovered from Graafian follicles of different sizes in the presence of hormones shows that FSH is more potent than LH for inducing loss of cohesion, and in several species oocytes with a typical corona radiata can regularly be obtained in this way (Pl. 1, Figs 2 and 3). Prolactin is without effect, and no spontaneous loosening of the cumulus cells has been observed without hormones (Thibault, 1972). It is not known if the specific FSH effect is necessary for final capacitation of the fertilizing spermatozoa as well as for oocyte release.

It is unlikely that the FSH effect is mediated by steroids, since cumulus cells do not show the typical cytoplasmic structure of steroid-secreting cells. Granular and agranular endoplasmic reticulum are present in various proportions, but the few cristae of the mitochondria are not of the tubular type (Zamboni, 1974), although the Golgi complex is well developed and seems particularly active in the corona cells after the gonadotrophic surge (rabbit: Moricard et al., 1969; pig: Norberg, 1972).

When the whole follicle is cultured in the presence of FSH or FSH $+\mathrm{LH}$, the cumulus cells do not disperse. A limited cumulus cell response gives a moderate corona radiata, but we have rarely observed release of the oocyte inside the follicle as we have seen in the same species in vivo.

\section{FOLLIGULAR ENLARGEMENT, THINNING OF THE WALL AND OVULATION}

The synthesis of collagenase-like enzymes, probably under the influence of progesterone, seems to play a major role in the distension of the follicular wall and the rupture of the apex in vivo (see reviews by Blandau, 1970; Espey, 1974; Rondell, 1974). Enlargement of follicles during culture of follicles for 6-48 hr, or rupture and ovulation, has not been obtained, even with the preovulatory follicles of oestrous rabbits, with any type or dose of hormone in the culture medium. Similar results with hamster, cattle and monkey follicles corroborate the conclusions of Baker \& Neal (1972) on mice and Tsafriri et al. (1972) on rats. Modification of collagenous fibres surrounding the follicle does not seem to occur, and there is no increase in fragility of the isolated follicle during culture, as observed in vivo by Espey (1974).

During culture of follicles, it is impossible to simulate the ovarian epithelium, including the tunica albuginea, and the blood flow. Since the contents of the follicle are released outside the ovary, the ovarian epithelium is probably involved in the activation of collagenase activity. The rupture of cultured follicles has been described for ovarian fragments (Baker \& Neal, 1972) and whole ovaries (Fritz et al., 1965), but in vivo the decrease in the blood flow to a circumscribed area on the external surface of the follicle (Blandau, 1970) probably contributes to lysis of the granulosa and theca cells in that area.

The gas supply to a cultured follicle is evenly distributed through the fol- 
licular wall, except in the limited area on the grid where the follicle is in contact with the culture medium, and necrosis of this area has been reported (Moor et al., 1973).

The in-vitro system does not therefore provide valuable information on the ovulatory process since many factors, such as blood flow, presence of ovarian epithelium and ovarian contractility, are missing.

\section{CYTOPLASMIC AND NUGLEAR MATURATION OF THE OOCYTE}

\section{Culture of oocyte and cumulus}

When rabbit oocytes from preovulatory follicles are cultured with the cumulus cells in a suitable medium, they resume meiosis in a manner similar to that observed in vivo in preovulatory follicles after the gonadotrophic surge; the chronology of first polar body formation is the same, and the second maturation spindle usually appears quite normal. When such oocytes are cooled for $24 \mathrm{hr}$ at $10^{\circ} \mathrm{G}$ and then returned to $37^{\circ} \mathrm{C}$, they are parthenogenetically activated and cleave regularly (Thibault, 1973a). Fertilization of these oocytes has been obtained in vivo after transfer into a female mated $12 \mathrm{hr}$ earlier, and in vitro according to our routine procedure, but the fertilization process is abnormal. It begins as usual, but the sperm head remains morphologically unchanged, although migrating to the centre of the egg. The sperm nucleus does not swell immediately after penetration of the sperm head into the egg cytoplasm. The two pronuclei normally come into contact 3 to $5 \mathrm{hr}$ after penetration in the rabbit, but in the culture system the female pronucleus joins to an unchanged sperm head, suggesting that a factor, not synthesized in vitro, appears in the egg cytoplasm during natural oocyte maturation in vivo. We call this factor(s) the male pronucleus growth factor (MPGF).

The MPGF in the rabbit appears only in the oocyte 6 to $7 \mathrm{hr}$ after coitus, i.e. 3 to $4 \mathrm{hr}$ after the rupture of the germinal vesicle. Only testosterone and prolactin stimulate the synthesis of MPGF in vitro (Thibault et al., 1975). However, the normal development of the male pronucleus in human oocytes, cultured first in the presence of oestradiol for $4 \mathrm{hr}$, and then with $17 \alpha$-hydroxyprogesterone for $40 \mathrm{hr}$ (Soupart, 1973), seems to indicate that this steroid sequence, which normally occurs in vivo after the gonadotrophic surge, may induce the synthesis of MPGF by the oocyte itself.

\section{Culture of the Graafian follicle}

Absolutely normal oocytes can be produced by culture of whole preovulatory follicles of rabbits in TCM $199+15 \%$ fetal calf serum $+15 \%$ normal rabbit serum $+20 \%$ chick embryo extract, $\mathrm{pH} 7 \cdot 3-7 \cdot 4$, gassed with air and $0.5 \%$ $\mathrm{CO}_{2}$, and at 5 to 10 bars. In the presence of 1 or $10 \mu \mathrm{g} \mathrm{FSH} / \mathrm{ml}$ and/or 1 or 10 $\mu \mathrm{g} \mathrm{LH} / \mathrm{ml}$, meiosis resumes, $8 \mathrm{hr}$ after the beginning of culture the first polar body is formed, and the second maturation spindle is present in all oocytes after $11 \mathrm{hr}$ (Thibault \& Gerard, 1973). These oocytes have been recovered inside the follicle after $12 \mathrm{hr}$ of culture and transferred into one oviduct of a doe mated $9 \mathrm{hr}$ previously with a normal buck. Just before transfer, all the follicles in the ovary adjacent to the oviduct receiving the cultured oocytes are 
destroyed. Oocytes of the contralateral ovary, shed in the corresponding tube, serve as controls. Experimental oocytes show that MPGF is synthesized in vitro in the follicle since the male pronucleus swelling proceeds exactly as in the control eggs (Thibault \& Gerard, 1973).

Oocytes were transferred to the oviducts of two rabbits after intrafollicular maturation in vitro and permitted to develop to term. Normal young of both sexes were produced from $60 \%$ of the transferred oocytes and were themselves fertile. Similar experiments conducted with 60- to 82-day-old immature rabbits, or adult hamsters and monkeys, showed that oocytes with the second metaphase spindle may be obtained in Graafian follicles cultured in the presence of gonadotrophins.

\section{ATRESIA in vivo AND PYKNOSIS in vitro}

The maturation of follicular oocytes in vitro needs culture conditions in which the different layers of the follicle (theca, granulosa and cumulus cells) do not show signs of pyknosis, because it is known that the oocyte is able to resume meiosis spontaneously when granulosa cells degenerate in vivo or in vitro (Foote \& Thibault, 1969). Different techniques were used to increase the oxygen available inside the follicle or to impoverish the culture medium.

Table 1. The evolution of nuclear maturation in vitro of intrafollicularoocytes of Macaca fascicularis

(from Thibault, 1973b)

\begin{tabular}{lccc}
\hline Nuclear stages & $\begin{array}{c}\text { In ovary } \\
\text { at Day } 7 \text { of } \\
\text { the cycle }\end{array}$ & $\begin{array}{c}\text { After } \\
24 \mathrm{hr} \\
\text { of culture }\end{array}$ & $\begin{array}{c}\text { After } \\
48 \mathrm{hr} \\
\text { of culture }\end{array}$ \\
\hline Dictyate & 9 & 0 & 0 \\
Prometaphase & $4^{*}$ & 8 & 14 \\
Metaphase I & $2^{*}$ & 5 & 2 \\
Metaphase II & $9^{*}$ & 0 & 4 \\
\hline
\end{tabular}

Culture conditions were TCM $199+20 \%$ fetal calf serum $+20 \%$ monkey serum; HMG $+\mathrm{HCG}$; air $+0.5 \% \mathrm{CO}_{2}$; and 10 bars pressure.

* In pyknotic follicles.

Preservation of granulosa and cumulus cells was obtained in rabbit, monkey and hamster when the gas pressure (air and $0.5 \% \mathrm{CO}_{2}$ ) was increased to 5-10 $\mathrm{kg} / \mathrm{cm}^{2}$. In such conditions, all follicular layers remained absolutely normal after 15-24 hr of culture and nuclear maturation occurred in practically all the oocytes in the presence of FSH, LH or FSH+LH (Thibault \& Gerard, 1973). The results were similar for oocytes of large preovulatory follicles of unmated oestrous rabbits, and for oocytes from small follicles $(<1$ $\mathrm{mm}$ ) from 60-82-day-old rabbits which had been treated $24 \mathrm{hr}$ before explantation with crude horse pituitary extract, a potent stimulant of follicular growth in mature rabbits (Pl. 1, Fig. 4). Meiotic division was also observed in the macaque when small follicles $1.0-2.0 \mathrm{~mm}$ in diameter were cultured under $10 \mathrm{~kg} / \mathrm{cm}^{2}$ pressure (Table 1). The same technique was also satisfac- 
PLATE 1

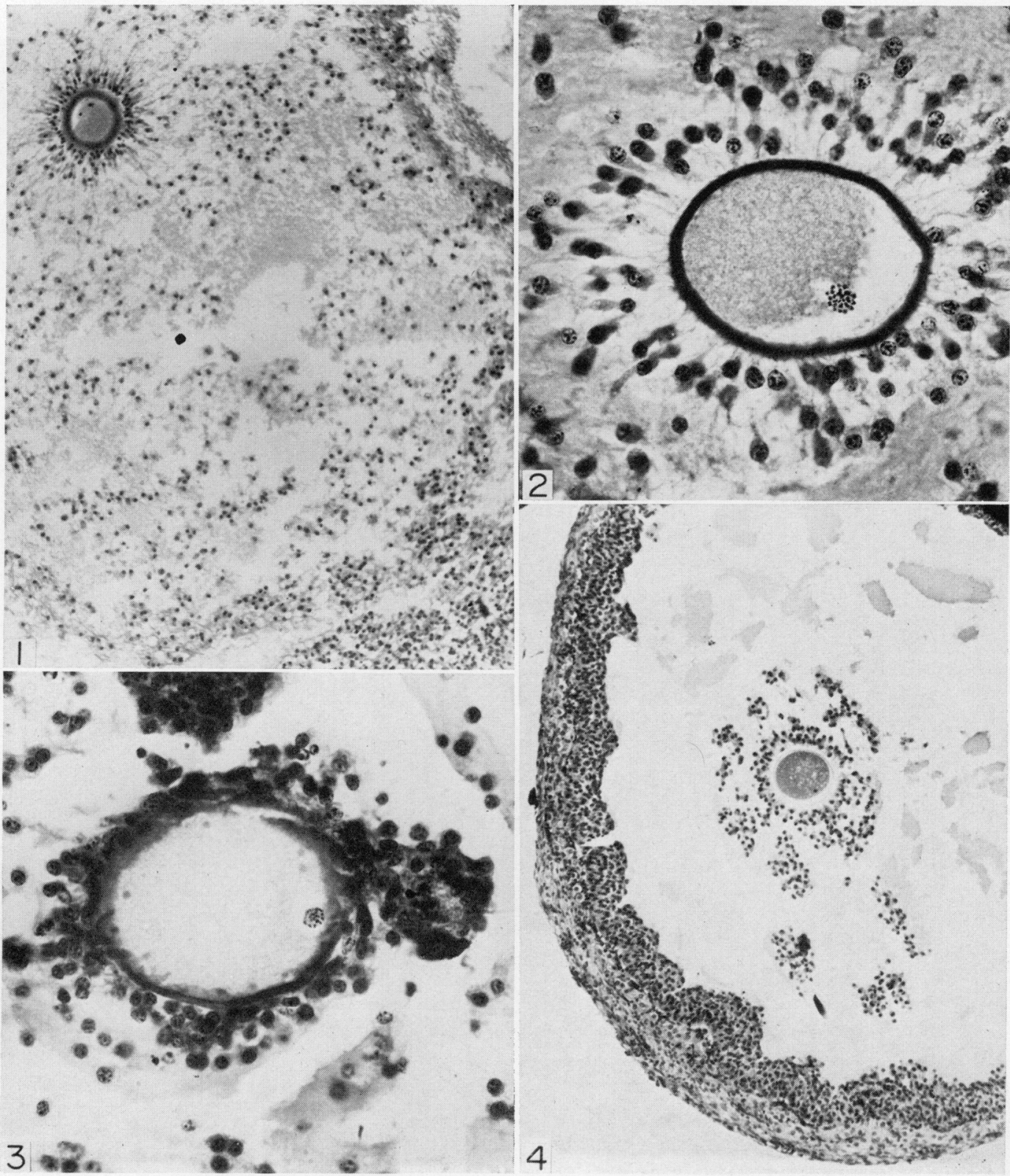

FIG. 1. Follicle of a cow just before ovulation showing the oocyte and its corona free in the follicular fluid and the loosened granulosa cells. The oocyte is at metaphase II and has produced the first polar body.

FIG. 2. Cumulus cells and oocyte from a medium-sized calf follicle after $24 \mathrm{hr}$ of culture in the presence of ovine FSH. The oocyte is in metaphase I and has a typical corona radiata, an aspect similar to that shown in Fig. 1.

Fig. 3. The cumulus cells and oocyte from a medium-sized sheep follicle after $24 \mathrm{hr}$ of culture in the presence of ovine LH. The oocyte is in metaphase II, but there is no loosening of the cumulus cells.

FIG. 4. A small follicle, from an immature rabbit, cultured in the presence of FSH and LH under $10 \mathrm{~kg} / \mathrm{cm}^{2}$ gas pressure. Meiosis has resumed and has reached metaphase II. There are no signs of pyknosis and early luteinization of the granulosa cells can be seen.

(Facing p. 608) 
PLATE 2
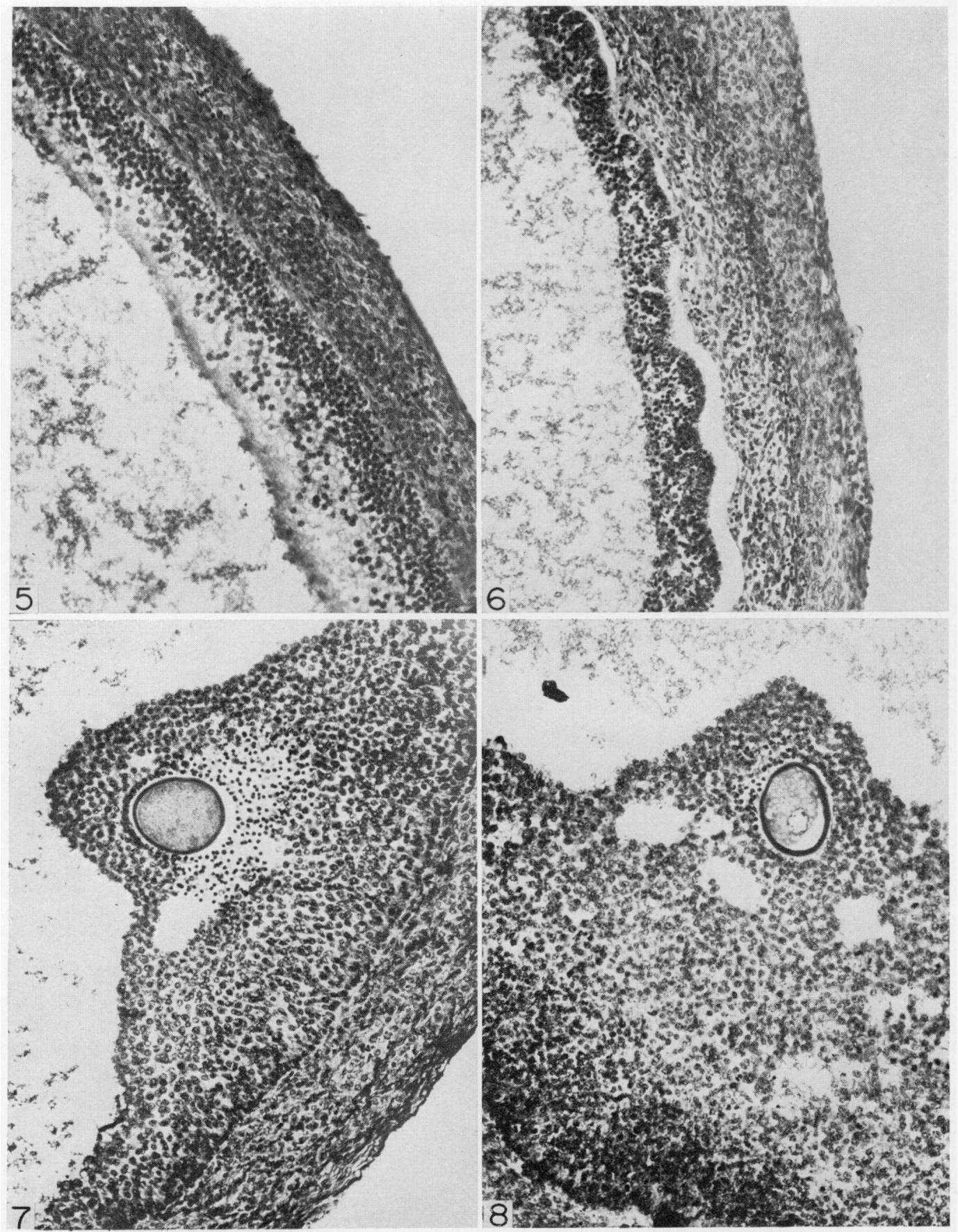

FIG. 5. Calf follicle cultured in the presence of bovine FSH showing strong secretory activity of the granulosa cells.

FIG. 6. Calf follicle cultured at $\mathrm{pH} 7 \cdot 3$ for $24 \mathrm{hr}$ showing complete pyknosis of the granulosa cells and loosening of the granulosa and theca layers.

Fig. 7. Calf follicle cultured for $12 \mathrm{hr}$ at $\mathrm{pH} 7.8$ in a medium containing $40 \%$ calf serum in the presence of FSH. There is a large area of pyknosis in the cumulus, but other cells are normal.

Fig. 8. Calf follicle cultured in the same conditions as those for Fig. 7 but with a reduced quantity of serum, resulting in a limited number of pyknoticictumulus s cells som at 04/26/2023 12:44: 00PM 
tory for the hamster. These results agree well with those of Baker \& Neal (1972) for the mouse. Thus, normal maturation under the influence of gonadotrophins can be easily obtained in vitro if the oxygen available inside the follicle for the granulosa and cumulus cells is increased (Thibault et al., 1975).

The relationship between gonadotrophic stimulation of granulosa and cumulus cells and their metabolic requirements has been investigated by culture of follicles from 3-month-old calves. Follicles were collected from calves pretreated with fluorogestone acetate and PMSG in order to obtain an homogenous population of non-atretic follicles $2-4 \mathrm{~mm}$ in diameter (Arrau, 1974). As indicated above, FSH loosens the cumulus cells very rapidly. Moreover, FSH stimulates the secretory activity of granulosa cells throughout the follicle (Pl. 2, Fig. 5). LH has less effect on cumulus cells and does not enhance the secretory activity of the granulosa layer. If the culture medium is at $\mathrm{pH}$ $7 \cdot 3-7 \cdot 4$, the cumulus cells become pyknotic in a few hours, and pyknosis appears in the granulosa and theca interna cells, which become dissociated (P1. 2, Fig. 6). Granulosa and theca cells can be preserved by increasing the $\mathrm{pH}$ to 7.8 and even to 8.0 , but necrosis of the cumulus cells is not prevented (PI. 2, Fig. 7). If LH or PMSG is used instead of FSH, pyknosis is localized to small areas of the cumulus mass, generally proximal to the oocyte. Normal metaphase II has been obtained after $30 \mathrm{hr}$ of culture.

Complete preservation of these cells, however, is obtained only after impoverishment of the culture medium. When the serum content is limited to $20 \%$, there is no sign of pyknosis in the presence of $\mathrm{PMSG}$ or $\mathrm{LH}$, and necrosis is limited when FSH is present (Pl. 2, Fig. 8).

It seems possible to conclude from these experiments that atresia in vivo may result from the inability of the ovary to respond to increases in gonadotrophin levels with the right changes of metabolism in the follicle. The decrease in the number of atretic follicles in vivo in calf ovaries during progestagen treatment, and the pronounced increase after either the endogenous surge of LH or PMSG + HCG treatment, show clearly that the gonadotrophin levels are important in the process of atresia.

RESPONSE OF SMALL- OR MEDIUM-SIZED FOLLICLES TO GONADOTROPHINS in vivo AND in vitro

In the experiments described above, resumption of meiosis has been obtained in small Graafian follicles of the macaque $(1.0-2.0 \mathrm{~mm})$ and immature rabbit $(<1 \mathrm{~mm})$, and in medium-sized follicles of calf and sheep $(2 \sim 6 \mathrm{~mm})$, and yet these follicles do not respond in vivo during the oestrous or menstrual cycle. As long as these follicles remain healthy, the oocyte stays in the dictyate stage, even if the gonadotrophin level increases. This difference in behaviour in vivo and in vitro suggests internal regulation by the ovary of follicular growth, as suggested by Peters et al. (1973), and of follicular sensitivity to gonadotrophins.

\section{ACKNOWLEDGMENTS}

We should like to thank the Laboratoire des Hormones Protéiques, G.N.R.S. 
(Dr Jutisz) for supplying us with FSH and LH. We are also grateful to the DGRST (contract No. 74-70514) and the Caisse Nationale de l'Assurance Maladie des Travailleurs Salariés for financial support. We also wish to thank P. Chené, P. Carpentier and R. Scandolo for technical assistance and Mrs Alice Daifuku for the preparation of the manuscript.

\section{REFERENCES}

ARrau, S. (1974) Cinétique folliculaire et maturation ovocytaire chez le veau traité a l'acétate de fluoregestone et la PMSG. Annls Biol. anim. Biochim. Biophys. 14, 633-650.

BAKER, T.G. \& NeAL, P. (1972) Gonadotrophin-induced maturation of mouse Graafian follicles in organ culture. In Oogenesis, pp. 377-396. Eds J. D. Biggers \& A. W. Schuetz. University Park Press, Baltimore.

Blandau, R.J. (1970) Growth of the ovarian follicle and ovulation. Progr. Gynec. 5, 58-76.

EDWARDs, R.G. (1974) Follicular fluid. F. Reprod. Fert. 37, 189-219.

EsPEy, L.L. (1974) Ovarian proteolytic enzymes and ovulation. Biol. Reprod. 10, 216-235.

Foote, W.D. \& Thibault, C. (1969) Recherches expérimentales sur la maturation in vitro des ovocytes de truie et de veau. Annls Biol. anim. Biochim. Biophys. 9, 329-349.

Fritz, H.I., Cho, W.K. \& BigGers, J.D. (1965) Ovulation from whole ovaries of mice in organ culture. 7. Cell Biol. 27, 31A, Abstr.

Menezo, Y. \& Testart, J. (1975) Etude comparée du serum sanguin et du liquide folliculaire preovulatoire chez la Vache. Annls Biol. anim. Biochim. Biophys. 15, 1-8.

MooR, R.M., HAY, M.F., McIntosh, J.E.A. \& CALDWELl, B.V. (1973) Effect of gonadotrophins on the production of steroids by sheep ovarian follicles cultured in vitro. F. Endocr. 58, 599-611.

Moricard, R., Gothie, S. \& Traub, A. (1969) Modifications ultrastructurales des cellules periovocytaires apparaissant après coit avant l'ovulation. Effet des gonadotrophines chez la lapine. Gynec. Obstet. 68, 79-92.

Norberg, H.S. (1972) The follicular oocyte and its granulosa cells in domestic pig. Z. Zellforsch. mikrosk. Anat. 131, 497-517.

Peters, H., Byskov, A.G. \& FAber, M. (1973) Intraovarian regulation of follicle growth in the immature mouse. In The Development and Maturation of the Ovary and its Functions, pp. 20-23. Ed. H. Peters. Excerpta Medica, Amsterdam.

RonDELl, P. (1974) Role of steroid synthesis in the process of ovulation. Biol. Reprod. 10, 199-215.

SouPART, P. (1973) The need for capacitation of human sperm: functional and ultrastructural observations. In Transport, Survie et Pouvoir fécondant des Spermatozoides chez les Vertébrés, pp. 407-434. Eds E. S. E. Hafez \& C. Thibault. INSERM, Paris.

Thibault, C. (1972) Final stages of mammalian oocyte maturation. In Oogenesis, pp. 397-411. Eds J. D. Biggers \& A. W. Schuetz. University Park Press, Baltimore.

ThiBault, C. (1973a) In vitro maturation and fertilization of rabbit and cattle oocytes. In Regulation of Mammalian Reproduction, pp. 231-240. Eds S. J. Crozier, P. Corfman \& P. K. Condliffe. C. C. Thomas, Springfield, Illinois.

ThiBaULT, C. (1973b) Experimental approaches to normal and abnormal mammalian oocyte maturation and ageing. In Aceidents Chromosomiques de la Reproduction, pp. 233-240. Eds J. C. Boué \& C. Thibault. INSERM, Paris.

Thibault, C. \& Gerard, M. (1973) Cytoplasmic and nuclear maturation of rabbit oocytes in vitro. Annls Biol. anim. Biochim. Biophys. 13, Suppl. 145-156.

Thibault, C., Gerard, M. \& Menezo, Y. (1975) Acquisition par l'ovocyte de lapine et de veau du facteur de décondensation du noyau du spermatozoïde fécondant. Annls Biol. anim. Biochim. Biophys. 15, (in press).

TSAFRIRI, A., LiNDNER, H.R., ZoR, U. \& LAMPREGHT, S.A. (1972) In-vitro induction of meiotic division in follicle-enclosed rat oocytes by LH, cyclic AMP and prostaglandin $\mathrm{E}_{2}$. F. Reprod. Fert. 31, 39-50.

ZAMBoni, L. (1974) Fine morphology of the follicle wall and follicle cell-oocyte association. Biol. Reprod. $10,125-149$. 